
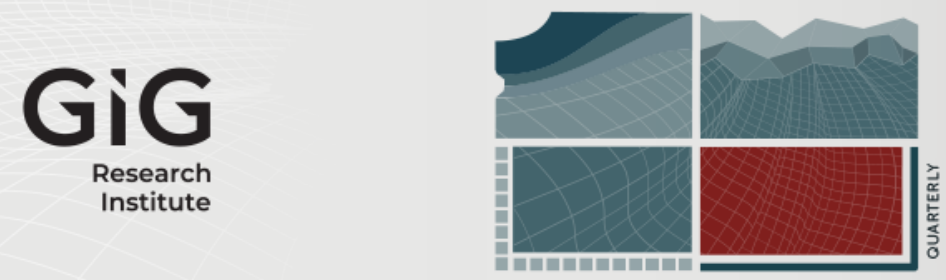

JOURNAL

OF

SUSTAINABLE

MINING

\title{
"Surviving and growing up with illegal status": The Analysis of Socio-Economic Household, Potential Conflict, the Environmental Damage, and Vulnerability of Local Community to Disaster
}

Author(s) ORCID Identifier:

Sofyan Syahnur (iD) 0000-0003-3736-7917

Yossi Diantimala (iD) 0000-0001-5301-1502

Follow this and additional works at: https://jsm.gig.eu/journal-of-sustainable-mining

Part of the Business Law, Public Responsibility, and Ethics Commons, Environmental Studies Commons, Industrial Technology Commons, and the Sustainability Commons

\section{Recommended Citation}

Syahnur, Sofyan and Diantimala, Yossi (2021) "'Surviving and growing up with illegal status": The Analysis of Socio-Economic Household, Potential Conflict, the Environmental Damage, and Vulnerability of Local Community to Disaster," Journal of Sustainable Mining: Vol. 20 : Iss. 3 , Article 3.

Available at: https://doi.org/10.46873/2300-3960.1061

This Research Article is brought to you for free and open access by Journal of Sustainable Mining. It has been accepted for inclusion in Journal of Sustainable Mining by an authorized editor of Journal of Sustainable Mining. 


\title{
"Surviving and growing up with illegal status": The Analysis of Socio-Economic Household, Potential Conflict, the Environmental Damage, and Vulnerability of Local Community to Disaster
}

\begin{abstract}
This study aims to analyze, from social-economics and environmental perspectives, how illegal gold mining survives and grows with its illegal status. Generally, illegal mining has a positive impact on the socio-economy of all parties involved. However, mining activities cause environmental damage and pollution so that the local community is vulnerable to disaster and potential conflict. This research was conducted at an illegal mining site in Aceh, the western province of Indonesia. To describe the primary data, it employs a descriptive qualitative method. The purposive sampling method is used to select key informants. The results show an increasing income of all stakeholders involved. To minimize environmental damage and pollution, illegal mining uses a very simple-but very environmentally friendly-tool, "Asbhuk", which does not harm the sustainability of the natural environment, especially the use of wells and mountain springs. Nevertheless, natural disasters often occur in the mining area, such as overflowing rivers and landslides caused by heavy rainfall. It is a negative impact from changes in the structure of mining land, forest encroachment, and the expansion of the river. There is no significant conflict between direct and indirect parties engaged in illegal mining activities. The direct parties desire this mining activity to be conducted by artisanal and small groups.
\end{abstract}

\section{Keywords}

Illegal gold mining, socio-economic, conflict, environmental damage, vulnerable to disaster, asbhuk - a traditional sluice box, artisanal and small-scale gold mining.

\section{Creative Commons License}

(c) $($ ) $\ominus$

This work is licensed under a Creative Commons Attribution-Noncommercial-No Derivative Works 4.0 License.

\section{Cover Page Footnote}

Acknowledgements The author would like to thank the team of local enumerators who have gone to great lengths to help the research team to obtain information by distributing questionnaires and in depth interviews to owners, investors, miners, local governments, and communities around illegal gold mines which are very closed and secret. In addition, the team of local enumerators faced very tough natural challenges in the field. Walking in mountainous areas, through several rivers by means of a raft crossing, and being far from the village to get this research information can be completed well. Hopefully, this research will be more valuable and useful for the sustainability of gold mining in Indonesia and in the world. 


\title{
"Surviving and growing up with illegal status": The analysis of Socio-Economic household, potential conflict, the environmental damage, and vulnerability of local community to disaster
}

\author{
Sofyan Syahnur ${ }^{a}, *$, Yossi Diantimala ${ }^{\mathrm{b}}$
}

\begin{abstract}
${ }^{a}$ Economics Development Department of Economics and Business Faculty, Universitas Syiah Kuala (USK), Darussalam, Banda Aceh, 23111, Indonesia

${ }^{\mathrm{b}}$ Accounting Department of Economics and Business Faculty, Universitas Syiah Kuala (USK), Darussalam, Banda Aceh, 23111, Indonesia
\end{abstract}

\begin{abstract}
This study aims to analyze, from social-economics and environmental perspectives, how illegal gold mining survives and grows with its illegal status. Generally, illegal mining has a positive impact on the socio-economy of all parties involved. However, mining activities cause environmental damage and pollution so that the local community is vulnerable to disaster and potential conflict. This research was conducted at an illegal mining site in Aceh, the western province of Indonesia. To describe the primary data, it employs a descriptive qualitative method. The purposive sampling method is used to select key informants. The results show an increasing income of all stakeholders involved. To minimize environmental damage and pollution, illegal mining uses a very simple-but very environmentally friendly-tool, "Asbhuk", which does not harm the sustainability of the natural environment, especially the use of wells and mountain springs. Nevertheless, natural disasters often occur in the mining area, such as overflowing rivers and landslides caused by heavy rainfall. It is a negative impact from changes in the structure of mining land, forest encroachment, and the expansion of the river. There is no significant conflict between direct and indirect parties engaged in illegal mining activities. The direct parties desire this mining activity to be conducted by artisanal and small groups.
\end{abstract}

Keywords: illegal gold mining, socio-economic, conflict, environmental damage, vulnerable to disaster, artisanal and small-scale gold mining

\section{Introduction}

W

e analyze how illegal mining survives and grows with its illegal status. Previous studies have documented the activities, consequences, and benefits from illegal mining for miners and local communities around the mining so that the activities survive and grow. Individuals and small groups of miners and the local communities carry out the mining activities illegally. Haundi et al. [1], Mkodzongi et al. [2], and Owusu et al. [3] characterize these activities as artisanal and small-scale gold mining. Initially, the miners and most people around the area work as farmers and claim the land belongs to them so as they feel entitled to manage and extract the proceeds from the ground indefinitely [4]. Since they found that the gold mine has higher economic value, they switched their professions as miners with great income-generating [1]. Along with the development of the mining area, an individual and small group of investors and traders come to this area hence the area continues to develop, survive, and grow.

Higher positive benefits, such as higher income, drive the ability of artisanal and small-scale gold mining to survive and grow [3]. Mining and farming activities become miners' main livelihood which has to maintain for them to live [1]. Small-scale gold

Received 7 March 2021; revised 23 July 2021; accepted 6 August 2021.

Available online 27 August 2021

* Corresponding author.

E-mail address: kabari_sofyan@unsyiah.ac.id (S. Syahnur). 
mining has a positive impact on a broader economic structure. It includes economic and regional aspects, namely labor mobility, poverty reduction, and traffic mobility of commercial activities between regions. Local communities and miners already have a lot of experience and information about the negative impact of mining controlled by large scale, so they maintain the mining area as artisanal and smallscale. If they hand over control of this mine to the government to obtain legality, the community must be willing to accept that large-scale mining control the mining area.

The economic contribution from large-scale gold mining does not guarantee higher positive benefits for the miner and local communities concerning poverty reduction [5] and conflict between farmers and large-scale mining [4-6]. Large-scale mining takes over most of the population's agricultural land for mining operations so that miners who generally work as farmers lose their main livelihood, threaten the sustainability of their revenue and food security. The compensation package provided by the largescale mining to farmers is very detrimental to farmers cause of the limited knowledge and skills of farmers to negotiate with the company. Thus, the compensation package is not successful in reducing farmers' poverty because it did not cover the losses suffered by farmers whose land is forcibly taken by the company [5].

The other consequences of mining activities are environmental damages such as deforestation, water pollution, poor fertility of the soil, and limited access to land for agricultural productivity [7]. Miners and local communities are aware of the impacts that arise from environmental damage. Therefore, they voluntarily restore forest sustainability [8] and use simple and traditional technology [1] to avoid the use of chemicals that are harmful to the environment. Although, the negative impacts of mining activities have still occurred. They are changes in the structure of the land of former mining areas, deforestation that causes land and river surfaces wider, and the scarcity of ecosystem biodiversity and environmental quality. All of which are still at a tolerance level as a livable place to live.

The effect of small-scale illegal gold mining on miners' and farmers' livelihood and wealth is still debatable. There are two different conclusions regarding artisanal and small-scale mining. Adonteng-Kissi et al's. $[4,6]$ show that the income and social life of artisanal and small-scale mining in the Western Region of the South-Western part of Ghana have declined significantly. However, Haundi et al. [1] and Mkodzongi et al. [2] show that artisanal and small-scale mining increase miners' and farmers' welfare socially and economically. The main difference between the two groups of results lies in the conditions faced by artisanal and smallscale mining. In the South-Western part of Ghana, artisanal and small-scale mining operates side by side with large-scale mining. The large-scale receives high support from the government and prolarge-scale mining communities. Therefore, artisanal and small-scale operations are under pressure from large-scale mining, the government, and society in favor of large-scale.

In contrast to Southwestern Ghana, artisanal and small-scale gold mining in Zimbabwe has the support of the Zimbabwean government so that farmers can work as miners and manage these natural resources freely [2]. It has a positive impact on the socio-economic life of farmers and miners who are local communities in the mining area. Local communities can manage natural resources as their income-generating to improve their life and livelihood. As in Zimbabwe, artisanal and small-scale mining in Malawi operates independently cause increasing socio-economic benefits for local communities who work as farmers and miners [1]. Moreover, Haundi et al. [1] show that artisanal and small-scale becomes an alternative for farmers and local communities when farming is less profitable for them in the dry summer. Then, it increases their income and improves their livelihoods. Besides, the revenue of miners increases from the many classifications of mining work in one mining area. Contrary to Adonteng-Kissi [5] and Owusu et al. [3] quantitatively examine the impact of artisanal and small-scale mining on the socio-economic life of farmers and miners in Ghana in 25 years, from 1990 to 2016. The results show that the income of miners increases, the unemployment rate decreases, and the commercialization of the area around the mining area increases.

Based on the different results, this study contributes to the debate by investigating a case of artisanal and small-scale gold mining which illegally survive and grow in Aceh, Indonesia. Beutong Illegal Gold Mining (hereafter Beutong IGM) is classified as artisanal and small-scale gold mining [1] in terms of legality, the tools used are still traditional, and the workers who work there are individuals and groups. Beutong Illegal Gold Mining is a very well-known place where it is going on in Aceh, one of the most western provinces of Indonesia. The status of these mines is illegal but very well known. Miners carry out their gold mining activities openly. Heavy equipment makes noise, and the work goes on every day. Usually, illegal activities are not well-known and are conducted in secret [9]. The unlawful status has long been attached to the gold mining at 
Beutong. However, these activities are getting bigger and more extensive. A mining community said:

"Initially (before the 2000s), it was only around the river; now it has expanded to a protected forest and mountainous areas. At its peak in 2018, there were more than 500 active miners and hundreds of pieces of heavy equipment, like a parade of backhoes (there were more than 200 backhoes), working in the mining area to produce on average of 20 to $100 \mathrm{~g}$ of gold per day per small group. It is not only miners who work there; they work together in a group consisting of land owners, investors, and several miners using 1 or 2 backhoes for one mining area. These workers already have their mining areas. It prompted the government to close the area and officially prohibit the community from mining there. However, the community did not pay attention to the prohibition. Not long after the issuance of the mining ban, the people around the mining area returned to mine illegally there." (Speaker 1, the mining community).

Nowadays, around 100 active miners and several backhoes are operating there. They carry out these activities clandestinely in mining areas which are difficult to reach by the security apparatus and local governments. Accordingly, mining operations began to shift towards more remote villages and even towards protected forests. It threatens those forests and environmental sustainability. The damage to the environment and protected forests that arise from Illegal Gold Mining (henceforward IGM) is not worth the benefits received by hundreds of miners. For miners, $20-50 \mathrm{~g}$ of gold per day per small group is the standard amount of profit they get after deducting their main operating costs from renting backhoes and buying diesel oil for operations. Implicitly, to maintain the continuity of mining activities, miners must be able to find a minimum of $20 \mathrm{~g}$ of gold per day to meet the operational costs of this mining activity. However, the environmental and forest damage is borne not only by the miners but also by the wider community.

The local government has not succeeded in turning this mining site into a legal gold mine that is managed in a modern and professional way so that it provides great benefits to the state, the community, and to the region as a whole. Based on our initial field research in the mining area, many obstacles prevent an agreement being reached between the government and the surrounding community. First, the three parties directly involved (owners, investors, and miners) do not want to leave their gold mining activities there and do not want to accept the government's offer to turn the area into an industrial area. Second, the government and communities around the mining area hold different opinions. The government believes that mining activities for personal interests and welfare are not justified because [10], Article 33 paragraph 3, explains that the earth, water, and natural resources contained therein are controlled by the state for the welfare of the people. The community thinks that they will be better off together if the mine is managed by the community. If the government managed it, the government would hand over this mining area to entrepreneurs, meaning only a few people would enjoy the results. Third, the mining land is claimed as private property, so the community feels free to exploit it. The fundamental question is why the central and local governments do not use their powers to manage this place in accordance with the prevailing laws. The governments should be able to force people to comply with the law. This indicates that there are influential, invisible stakeholders who play a very important role in the mining activities.

This study does not investigate this "invisible hand", but investigates, instead, the hidden factors from an economics perspective which may have a big influence on how this place can survive and even grow bigger despite its illegal status. Contribution to the socio-economic improvement of the parties involved directly and indirectly may be the main factor behind the status of this place continuing to be illegal. However, besides that, the existence of this illegal mining triggers a potential conflict [9] between parties who are directly involved (miners, mine owners, and investors) and parties who are not directly involved, such as local governments and communities around the mining area. Damage to the environment, protected forest areas, and mountains can easily occur due to exploitative activities that do not follow the rules, do not have good planning, do not follow a clear operational procedure system, and do not have a control system regarding which areas can be exploited which cannot. This is because exploitation of the mining area does not follow the applicable legal regulations $[8,9]$.

This illegal mining is an economic activity that exploits natural resources without mining permits of the kind that is often carried out in many developing countries $[9,11,14]$. Mining permits are stipulated by the local government and regulated also by central government $[9,11]$. In Indonesia, IGM is a type of natural resource extraction that is prohibited by local and central government regulations. In reality, however, IGM operations are still very prevalent in Aceh, both openly and secretly. In general, 
there are strong indications that the pattern of illegal operations in gold mining areas in Aceh principally conforms with the same prototype, namely nomadic and traditional activity.

The results of this study are crucial to be conveyed through this publication to support the Sustainable Development Goals (SDGs) to maintain a balance between social, economic and environmental sustainability. Illegal mining is realized as an activity that can damage environmental sustainability and harm the socio-economic life of local communities [7]. However, the results of this study show that not only harms social life and vulnerable to the natural disaster, but illegal mining also has a positive impact on the economy of the communities and the environment around the mining area. Illegal miners in Beutong preserve the environment and forests by replanting exploited forests with rubber trees and using simple environmentally friendly technology that does not pollute the air, water and soil. The results of this study are in line with the studies of $[14,15]$ which show that mining is closely related to the SDGs. Increasing people's income can eliminate poverty (SDGs 1), eliminate hunger (SDGs 2), and reduce inequalities (SDGs 10). The use of environmentally friendly technology can develop industry, innovation, and infrastructure (SDGs 9).

This study aims (1) to investigate the impact of IGM on socio-economic life, environmental damage, potential conflicts between parties who are directly involved (miners, mine owners, and investors) and parties who indirectly involved, such as local governments and communities around the mining area. The five parties examined in this research are also the main focus of this research; (2) to analyze the impact of IGM on the extent of local communities' vulnerability to disasters; and (3) to find possible solutions in order to reduce the impact of IGM by adopting a more precise mining technology to be used as a mercury-free alternative. This study is very important bearing in mind that there has not been any previous study that analyzed conditions similar to those in the Beutong mining area.

\section{Literature review}

Mining activities are often carried out regardless of the level of damage to the socio-economic life of the local community, the environment, and forest ecosystems $[8,9,14,16,17]$. The negative impact of mining activities is considered to be greater than the positive impacts such as reducing poverty due to increasing income of the community around mining which is, nevertheless, short-term [5]. Moreover, the negative impacts of mining can be seen in the land degradation, landslides and floods, damage to water quality, pollution, damage to productive community lands (such as plantations, rice fields, fisheries, and farming), decreasing diversity of flora and fauna, vulnerability to disease, damage to the beauty of the environment $[8,9,17-19]$.

The local government will be responsible for the costs of restoration in the wake of environmental damage resulting from the mining damages [11]. Besides this, the local government will be accountable for the costs of conflicts of interest which harm the lives of communities in mining areas and communities adjacent to mining areas [6]. Illegal mining activities may have a bigger negative impact than legal mining because illegal operations do not follow certain established procedures that are implemented by legal mining, and there are no binding rules that must be adhered to Boadi et al. [9] and Duff et al. [11].

The track record of illegal mining research in various countries can be categorized into three types. The first is related to the impact of illegal mining on the socio-economy and environment $[8,9,14,17$, 19-21]. Amoah et al. [17] using GPS and ArGis approaches to analyze the damage caused by illegal mining. Their results explained that the negative effect of illegal mining is destroying forests, losing habitat and biodiversity, and even impacting the lives of rural communities. Kitula et al. [21] used a descriptive approach in assessing this relationship between illegal mining, socio-economic and environmental damage. The results of his research underlined that the negative impact can be reduced if the government provides technical support and improved regulations in conducting mining. Al Rawashdeh et al. [19] and Horsley et al. [20] examined the relationship between mining and development as reflected in changes in the economy, socio-culture, health, politics, the environment, poverty, unemployment, and education. The second correlates with the impact of illegal mining and alternative technology as a traditional tool in filtering gold by using mercury [22,23]. Reducing the use of mercury requires government intervention to support mercuryfree technology and also monitoring of mercury in the environment. The third deals with the impact of illegal mining on socio-economic conflicts. Adonteng-Kissi et al. [6], Duff et al. [11], and SánchezVázquez et al. [18] reveal negative impacts of traditional mining on the environment and socio-economic conflicts. The findings conclude that it is necessary to redefine the legal mining framework and support the training process for workers to reduce social and environmental conflicts. 


\subsection{Regulatory framework}

In general, Article 33 Paragraph 3 of Ref. [10] states that the earth, water, and the natural resources contained therein are controlled by the state and used for the greatest prosperity of the people. The state has the power to manage minerals and coal as natural resources contained in Indonesia. The management of natural resources is carried out optimally, efficiently, transparently, sustainably, and environmentally, and fairly to obtain the maximum benefit for the prosperity of the people in a sustainable manner. The government has limitations in the exploration and exploitation of these natural resources. Therefore, the government needs the role of its citizens to carry out natural resource processing activities under the control and monitoring of the government. The form of government control and monitoring is described in Ref. [24] regarding Protection and Management of the Environment. This regulation regulates the instruments that must be owned by business entities or individuals (groups) that will manage mining to prevent environmental and forest damage due to mining activities. To support these national regulations, the Aceh Government issue [25] regarding Criteria and Procedures in Providing Incentives for Environmental Management in Aceh. To support these goals, resource processing should use environmentally friendly technologies that do not damage the environment.

Furthermore, Ref. [26] concerning Mineral and Coal Mining in Article 35 explains that mining activities can be performed in three forms, namely (1) IUP (mining business permit) to carry out this mining business must have (a) Exploration IUP is a business permit that given to carry out the stages of exploration investigation activities, and feasibility studies; and (b) Production Operation IUP is a business license granted after the completion of the Exploration IUP implementation to carry out the stages of production operation activities; (2) IPR (People's Mining Permit) is a permit to carry out mining business in a people's mining area with a limited area and investment; and (3) IUPK (Special Mining Business Permit) is a permit to carry out mining business in an unusual mining business permit area. This IUPK consists of (a) Exploration IUPK is a business license granted to carry out the stages of a general investigation, exploration, and feasibility studies activities in a particular mining business permit area. (b) Production Operation IUPK is a business license granted after completing the Exploration IUPK to carry out the stages of production operation activities in the specific mining business permit area. In particular, in the management of mining business permits, business entities, cooperatives, and individuals must meet many criteria that need to be prepared, respectively, as set out in Articles 39 and 65 (IUP), Article 67 (IPR), and Articles 78 and 79 (IUPK). Based on Refs. [24,26] confirms that the legality of mining businesses carried out by business entities, cooperatives, and individuals must have one form of mining business license from the government such as IUP, IPR, and IUPK. If you do not have a business license document, mining is declared illegal. Based on the above regulations, in principle, the Indonesian government allows and supports artisanal and small-scale mining. However, artisanal and small-scale mining is hard to deal with complicated bureaucracy and to meet the requirements as stated in regulations and other technical documents.

\section{Materials and methods}

This study applied a descriptive qualitative method technique to describe the primary data that has been collected and tabulated. The main data was collected by direct observation and in-depth interviews to gather sufficient, in-depth, and detailed information. It led to an understanding of the involved parties' perceptions of the impact of Beutong IGM on the socio-economic life of households, environmental damage, potential conflict, and to create field documentation. The questionnaire was dynamic which designed with open-ended questions to both direct and indirect mining parties.

This study applies a dynamic questionnaire following the activities of IGM parties specifically. The questionnaire was formed with different questions to owners, investors, miners, government officials, and community members according to their activities and involvement in this Beutong IGM. These dynamic questions focus on the characteristics of respondents, social aspects, economic aspects, and environmental aspects. However, the structure of the question regarding respondents' expectations is the same for all respondents. It aims to analyze the level of complexity of the conflict among the IGM actors. The complete list of questions is illustrated in the Tables $1-5$ in the discussion section. Therefore, this study only uses a qualitative method (descriptive method) as a statistical tool to describe the actual situation of IGM activities in the Beutong Sub-district with field documentation. The frequency and percentage analysis described in Tables 1-5 are presented in the discussion of this study. Generally, this is something unique about this study. It provides very varied and specific information from the parties involved in the gold mining exploitation activities. 
The sampling has been carried out using the purposive sampling method intentionally identified to provide specific information about the population. The samples are owners, investors, miners, government officers, and community members who live around Beutong IGM areas (such as people living in the villages of Meunasah Pante, Meunasah Kreung, Babah Krueng, Kuta Bates, Blang Seumot, and Keude Seumot) and the local government. These villages were chosen because most of the people in these villages also work as gold miners and receive directly negative and positive impacts of the mining operations. Identifying key informants use judgment sampling as used by Adonteng-Kissi et al. [4]. The judgment sampling is appropriate to identify the specific targets to answer the designed questions in the questionnaire because we cannot plan and predict well who will be the key informant. The area is illegal, so very few people are willing to provide specific information regarding the impact of this IGM on the lives of people in that area. The key informants must have the knowledge, experience, and willingness to communicate required information based on the designed questionnaire. There are no restrictions on being a respondent.

The key informants interviewed include 18 owners $(\mathrm{O})$ of Beutong IGM locations, 17 investors (I) in Beutong IGM, and 16 miners (M) carrying out Beutong IGM. The total number of key informants interviewed who involved directly in Beutong IGM is 51. Meanwhile, the parties interviewed who are not directly involved in Beutong IGM comprise 12 government officials $(G)$ and 19 people living in the vicinity of the mining area $(\mathrm{C})$. In total, the number of key informants who are indirect parties related to IGM is 31 respondents. Overall, this research has interviewed 82 key informants related to IGM in Beutong Sub-district, Nagan Raya Regency.

During data collection, researchers were at the research site to observe directly the environmental conditions, mining processes, and the technology used. However, the researcher could not directly interview the key informants because they were very secretive and always avoided people, they considered as strangers. Therefore, the researcher used three well-known residents who met the academic qualifications as research enumerators to conduct the interviews. They are trained to do the interview properly. Then, the researcher accompanied the research enumerators when conducting interviews with key informants. However, interviews with key informants cannot be carried out in a planned and structured manner in a place that has been promised because key informants are very secretive. Interviews were conducted by directly meeting key informants at the mine site or a restaurant and immediately making an appointment to conduct interviews at that time.

\subsection{Description of study area}

This study uses primary data collected in the Beutong Sub-district, one part of Nagan Raya Regency which is located between $03^{\circ}-40-04^{\circ}-38^{\prime}$ North and $96^{\circ}-11-96^{\circ}-48^{\prime}$ East. Beutong is about $339 \mathrm{~km}$ distance from Banda Aceh, the provincial capital (see Fig. 1). The capital city of Beutong Sub-district is Babussalam with a total area of about $1017.32 \mathrm{~km}^{2}$ or 28.70 percent of the total area of Nagan Raya Regency. Beutong Sub-district has 24 villages, seven of which are in the IGM area. The sub-district is mainly nonrice field agricultural land (that can be explored for gold) and the main occupation of the community in the area is working on plantations. In general, the areas designated as IGM areas by communities have villages that are focused on non-rice agriculture such as rubber plantations, and non-agricultural land such as forests. The map of the location of IGM in Beutong Sub-district, Nagan Raya Regency, is carried out in three mining locations, namely along the river, around mountainous areas, and around residential plains (villages). The total population in Beutong Sub-district is 14,210 with 7108 males and 7102 females with 3200 households.

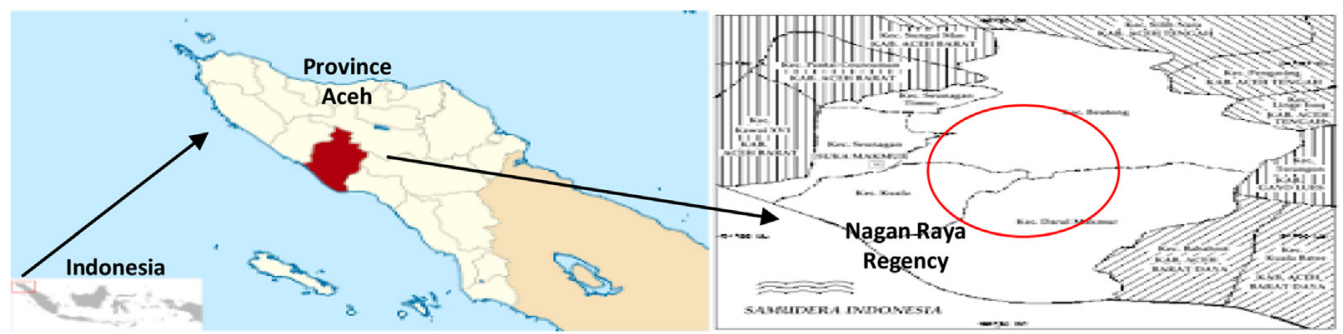

Source: Development Database of Nagan Raya Regency and Development Database of Beutong SubDistrict of Nagan Raya Regency, Development Planning Agency of Nagan Raya Regency, Aceh Province, 2017

Fig. 1. Map of IGM locations at the rivers and the mountains/plains in Beutong sub-district, Nagan Raya Regency, Aceh province [12,13]. 


\section{No Descriptions \\ $1 \quad$ Status of gold mining activity \\ 2 Status of government officer \\ $3 \quad$ Year of birth}

$4 \quad$ Place of birth

$5 \quad$ Last education level

$6 \quad$ Current job

$7 \quad$ Prior job before gold mining activity

8 Does gold mining activity have a license from the Regional Government?

9 When do the investors of gold mining activity start?

10 Are there any gold mining investors from Aceh

11 When does the gold mining activity start in this village?

12 When do you work as a gold mining worker?

\begin{tabular}{|c|c|c|c|c|c|}
\hline \multirow[t]{2}{*}{$\mathrm{P}$} & \multicolumn{5}{|c|}{ The Respondents' Responses } \\
\hline & Ownership & Rent & & & \\
\hline \multirow[t]{2}{*}{$\mathrm{O}$} & 72.2 & 27.8 & & & \\
\hline & Village gov officer & District gov officer & \multicolumn{3}{|l|}{ Regent gov officer } \\
\hline \multirow[t]{2}{*}{$\mathrm{G}$} & 16.7 & 25 & 58.3 & & \\
\hline & $20-30$ & $31-40$ & $>41$ & & \\
\hline $\mathrm{O}$ & 27.8 & 55.6 & 16.7 & & \\
\hline I & 35.3 & 64.7 & & & \\
\hline M & 62.5 & 18.8 & 18.8 & & \\
\hline \multirow[t]{2}{*}{$\mathrm{C}$} & 52.6 & 10.5 & 36.9 & & \\
\hline & Own Village & Other village & Aceh & & \\
\hline $\mathrm{O}$ & 55.6 & 44.4 & & & \\
\hline I & 88.2 & 11.8 & & & \\
\hline M & 93.8 & 6.3 & & & \\
\hline \multirow[t]{2}{*}{$\mathrm{C}$} & 52.6 & 26.3 & 21.1 & & \\
\hline & Elementary School & Junior High School & Senior High School and D3 & S1 & S2 \\
\hline $\mathrm{O}$ & & 22.2 & 38.9 & 38.9 & \\
\hline I & & & 17.6 & 82.4 & \\
\hline M & & 25 & 43.8 & 31.3 & \\
\hline G & & & 16.6 & 75 & 8.3 \\
\hline \multirow[t]{2}{*}{$\mathrm{C}$} & 21.1 & 5.3 & 42.1 & 31.6 & \\
\hline & Famer/Planter & Gov officer & Gold miner & Entrepreneur & Other \\
\hline I & & 11.8 & & 23.5 & 64.7 \\
\hline M & & & 75 & 6.3 & 18.8 \\
\hline \multirow[t]{2}{*}{ G } & 31.6 & 10.5 & 15.8 & & 42.1 \\
\hline & Farmer/Planter & Entrepreneur & Gov officer & Other & \\
\hline $\mathrm{O}$ & 38.9 & & 11.1 & 50 & \\
\hline I & & 62.6 & & 58.8 & \\
\hline $\mathrm{M}$ & 37.5 & 25 & & 25 & \\
\hline \multirow[t]{2}{*}{ G } & 68.4 & & 10.5 & 21.1 & \\
\hline & No & & & & \\
\hline $\mathrm{O}$ & 100 & & & & \\
\hline \multirow[t]{2}{*}{ I } & 100 & & & & \\
\hline & 2015-2016 & 2017-2018 & 2019 & & \\
\hline \multirow[t]{2}{*}{ I } & 41.2 & 47 & 11.8 & & \\
\hline & Yes & No & & & \\
\hline \multirow[t]{2}{*}{ G } & 75 & 25 & & & \\
\hline & 2015 & 2016 & 2017 & 2018 & \\
\hline $\mathrm{O}$ & & 16.7 & 66.7 & 16.7 & \\
\hline \multirow[t]{2}{*}{ G } & 91.7 & & & 8.3 & \\
\hline & 2015 & 2017 & 2018 & 2019 & \\
\hline
\end{tabular}




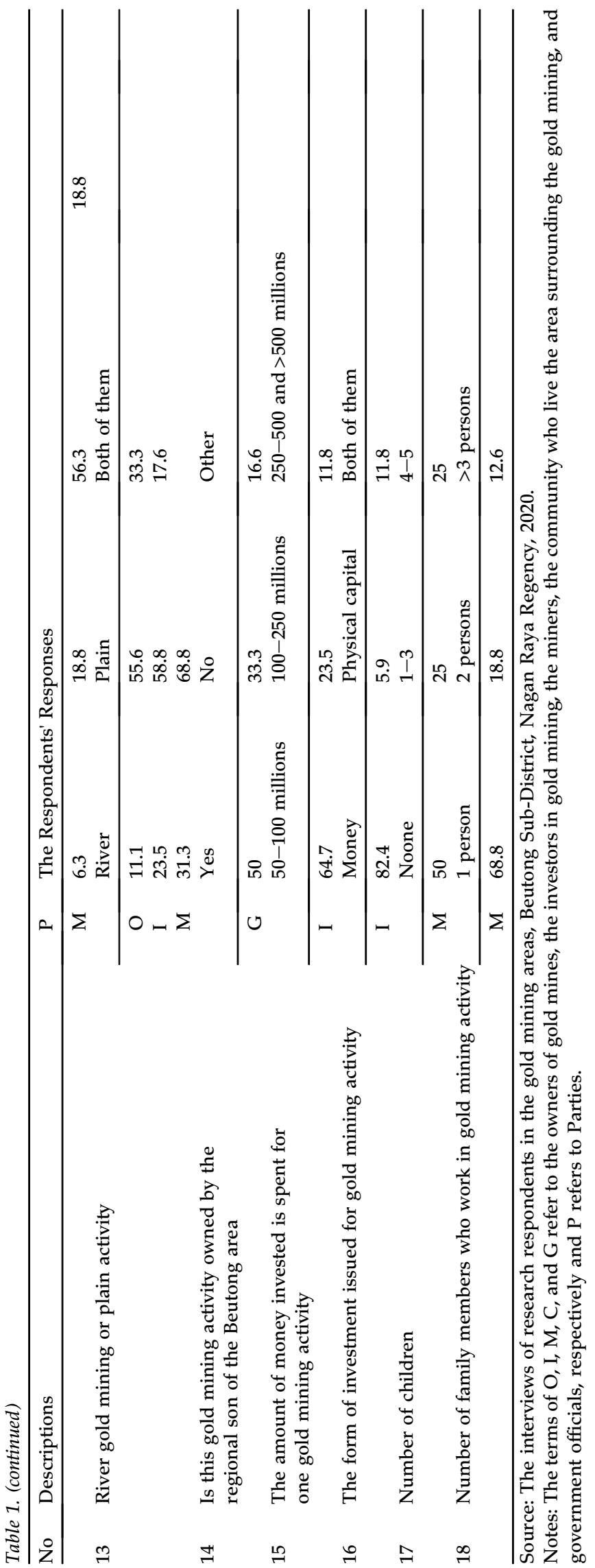

\subsection{The parties involved in the IGM}

There are five parties involved in Beutong IGM activity. Three parties, which are directly involved, comprise the miners who live around the mining area, those who buy the proceeds from the mining (the investors), and the party who owns the mining land (the owners). Two parties are not directly involved in this IGM activity, but they are in a risky position as a result of this IGM operation: these are the community that is only indirectly involved who live in the area surrounding the IGMs, and the local government which spends money on dealing with the impact of IGM (based on our initial field research to the mining area).

\section{Results and discussion}

\subsection{Demographic profile of key informants}

Table 1 presents the characteristics of key informants. On average, respondents representing the parties involved in IGM are still young. A total of $27.8 \%$ of owners and $62.3 \%$ of miners are aged $20-30$ years. As many as $55.6 \%$ of owners, $25.3 \%$ of investors, and $18.8 \%$ of miners are aged $31-40$ years. As many as $16.7 \%$ of owners, $64.7 \%$ of investors, and $18.8 \%$ of miners are 41 years old or older. These young people have a lot of enthusiasm to continue mining activities even though they are illegal. Most of the investors $(88.2 \%)$, miners $(93.8 \%)$, owners $(55.4 \%)$, and community $(52.6 \%)$ are local Beutong people who were born there. The respondents' educational backgrounds are quite good. As many as $8.3 \%$ of local government employees $(\mathrm{G})$ have a master's degree background. The undergraduate degree is the highest education level of $38.9 \%$ of owners, $82.4 \%$ of investors, $31.3 \%$ of miners, $75 \%$ of government officials, and $31.6 \%$ of community members. However, there are still $22.2 \%$ of owners, $25 \%$ of miners, and $5.3 \%$ of community members who have a junior high school education. In terms of current employment, $11.8 \%$ of investors and $15.8 \%$ of gold miners are government officials. This may be in conflict with the legal status of gold mining. The government officials should not work there as a miner because the status of the mining is illegal.

\subsection{The impact of IGM on socio-economic household}

In general, exploitation activities in IGM have a positive impact on the socio-economy of the parties involved [9], especially the owners and investors. Some socio-economic aspects of their lives improve 


\section{No Descriptions \\ 1 Is there a limitation on the age of workers for gold mining activity}

2 Is there insurance/severance pay for gold mining workers

3 Are the facilities at the gold mining activity self-financed

$4 \quad$ Is the access facility to the gold mining activity self-financed

$5 \quad$ Availability of educational infrastructure in the village

$6 \quad$ Number of family members who attend school

7 The number of family members who are no longer in school?

8 Availability of health infrastructure in the village

9 Availability of medical team in the village

10 Are there any migrants (people from other areas) living in this village

11 If yes, do they have a working relationship in gold mining activity

12 The company provides education \& health empowerment to the community

13 The company provides education \& health facilities

14 The company provides security \& hygiene facilities

P The Respondents' Responses

\begin{tabular}{llll} 
& Yes & No \\
\hline O & 16.7 & 83.3 \\
I & 11.8 & 88.2 \\
& Yes & No \\
\hline O & 16.7 & 83.3 \\
I & & 100 \\
G & 8.3 & 91.7 \\
& Yes & No \\
\hline O & 94.4 & 5.6 \\
I & 100 & \\
& Road & \\
\hline
\end{tabular}

$\mathrm{O}$

I 100

\begin{tabular}{lllll} 
& Elementary School & Junior High School & Senior High School & S1 \\
\hline $\mathrm{M}$ & 43.8 & 31.3 & 18.8 & 6.3 \\
$\mathrm{C}$ & 52.6 & 26.3 & 21.1 & \\
& 1 person & 2 persons & 3 persons & $>3$ persons \\
\hline $\mathrm{M}$ & 56.3 & 25 & 6.3 & 12.5 \\
$\mathrm{C}$ & 42.1 & 47.4 & 10.5 & \\
& Noone & 1 person & 2 persons & $>3$ persons
\end{tabular}

M 68.8

$63.2-10.5$

Integrated health post Community health center Other

\begin{tabular}{llll}
\hline M & 56.3 & 43.8 & \\
$\mathrm{C}$ & 52.6 & 36.8 & 10.5 \\
& General practitioner & Village midwife & Other \\
\hline M & 50 & 37.5 & 12.5 \\
$\mathrm{C}$ & 47.4 & 47.4 & 5.3 \\
& Yes & No & \\
\hline $\mathrm{M}$ & 87.5 & 12.5 & \\
$\mathrm{C}$ & 73.7 & 26.4 & \\
& Yes & No & \\
\hline $\mathrm{M}$ & 56.3 & 43.8 & \\
$\mathrm{C}$ & 47.4 & 52.7 & \\
& Yes & No & \\
\hline $\mathrm{M}$ & 6.3 & 93.8 & \\
& Yes & No & \\
\hline M & & 100 & \\
& Yes & No & \\
\hline
\end{tabular}


[9]. As is customary with IGM, there are no binding regulations that guarantee the welfare of society $[11,14]$ in terms of a social aspect [9]. There are no prohibitions or restrictions in the form of regulations regarding not doing something bad, there is no penalty for people who violate the regulations, nor are there any rewards for obeying the rules. This means everyone involved can do the things they want according to their needs even though they can harm and endanger other people, the environment, the nation, and the state. Table 2 presents the social aspects of IGM. Based on respondents' answers to the questions posed in the questionnaire, the authors conclude that there are several social aspects that are affected by the existence of the IGM, particularly young labor, risky work without guarantees, a lack of social benefits, and population increases, as follows:

Young Labor. The results of field observations show that the majority of illegal mining workers are young workers. The result is consistent with Ref. [7]. They play an important role to keep IGM sustainable in very difficult mining conditions. They have to cross rivers and mountains, drive heavy equipment (backhoe drivers), supply fuel stocks (transportation of fuel stocks), and even as the main worker in the gold mining area. More than $80 \%$ of the respondents said that there are no age limits. This opens up opportunities for young labor who should be able to continue their education to a higher level, and school-age workers (child labor) to work there as miners [27]. Table 1 indicates that $62.5 \%$ of miners are $20-30$ years old. This study has been unsuccessful in interviewing and giving questionnaires to young workers who were under 20 years of age. However, when we surveyed the location, we could see many young workers and child labor who were working there as miners. As many as $63 \%$ of respondents who came from the local community said that their family members had dropped out of primary school to work as miners. This is supported by the community's explanation in Table 1 which indicates that $21 \%$ of miners have an elementary school education background and $5 \%$ of miners have graduated from junior high school.

Risky work without guarantees. The miners who work in this area are divided into two groups. The first group works for their own interests, then sell their mining proceeds to investors. The second group works for the owners. They receive unconditional wages. These two groups work without accident insurance, work insurance, health insurance, and old age insurance like workers in the company. More than $80 \%$ of the owners and investors said no insurance or other job guarantees are given to 


\section{No Descriptions \\ 1 The gold mining activity uses labour from this area \\ 2 Gold mining activity opens up the considerable job opportunities in this area}

3 The gold mining activity uses workers from areas outside Aceh

4 Does this gold mining activity increase your family's income

$5 \quad$ Working in gold mining activity because

Whether gold mining activity is done as work

$7 \quad$ Whether the gold mining activity is done manually

$8 \quad$ Amount of gold earned per day

$9 \quad$ Market price per gram of mined gold

10 Where does this mined gold sell?

11 Does the gold mining buyer come from Beutong

12 Are the mined golds exported outside the Aceh region

13 Are mined golds exported to abroad

14 Is it economically profitable business from this gold mining activity?
P The Respondents' Responses

\begin{tabular}{|c|c|c|c|c|}
\hline & Yes & No & & \\
\hline $\mathrm{O}$ & 100 & & & \\
\hline I & 100 & & & \\
\hline \multirow[t]{2}{*}{ G } & 83.3 & 16.7 & & \\
\hline & Yes & No & & \\
\hline \multirow[t]{2}{*}{ G } & 83.3 & 16.7 & & \\
\hline & Yes & No & & \\
\hline $\mathrm{O}$ & 22.2 & 77.8 & & \\
\hline \multirow[t]{2}{*}{$\mathrm{I}$} & 11.8 & 88.2 & & \\
\hline & Yes & No & & \\
\hline \multirow[t]{2}{*}{$\mathrm{C}$} & 47.4 & 52.6 & & \\
\hline & Participation & Eagerness & No participation & \\
\hline \multirow[t]{2}{*}{$\mathrm{C}$} & 26.3 & 10.5 & 63.2 & \\
\hline & Main job & Part time job & Extra job & No participation \\
\hline \multirow[t]{2}{*}{$\mathrm{C}$} & 21.1 & 10.5 & 5.3 & 63.2 \\
\hline & Yes & No & & \\
\hline \multirow{2}{*}{ G } & 41.7 & 58.3 & & \\
\hline & $2-4 \mathrm{~g}$ & $5-10 \mathrm{~g}$ & $11-20 \mathrm{~g}$ & Uncertainty \\
\hline $\mathrm{O}$ & & 11.1 & 22.2 & 66.7 \\
\hline I & & 11.8 & 82.4 & 5.9 \\
\hline \multirow{2}{*}{$\mathrm{M}$} & 25 & 6.3 & 68.8 & \\
\hline & $700-800$ thousand/gram & 800-999 thousand/gram & 1 million/gram & \\
\hline $\mathrm{O}$ & 55.6 & 33.3 & 11.1 & \\
\hline \multirow{2}{*}{ I } & 35.3 & 41.2 & 23.5 & \\
\hline & Gold shop & Collector & & \\
\hline $\mathrm{O}$ & 100 & & & \\
\hline \multirow[t]{2}{*}{ I } & 64.7 & 35.3 & & \\
\hline & Yes & No & & \\
\hline \multirow[t]{2}{*}{ G } & 33.3 & 66.7 & & \\
\hline & Yes & No & & \\
\hline $\mathrm{O}$ & 11.1 & 88.9 & & \\
\hline \multirow[t]{2}{*}{$\mathrm{I}$} & 29.4 & 70.6 & & \\
\hline & Yes & No & & \\
\hline $\mathrm{O}$ & 5.6 & 94.4 & & \\
\hline \multirow[t]{2}{*}{ I } & & 100 & & \\
\hline & Yes & & & \\
\hline I & 100 & & & \\
\hline
\end{tabular}

(continued on next page) 


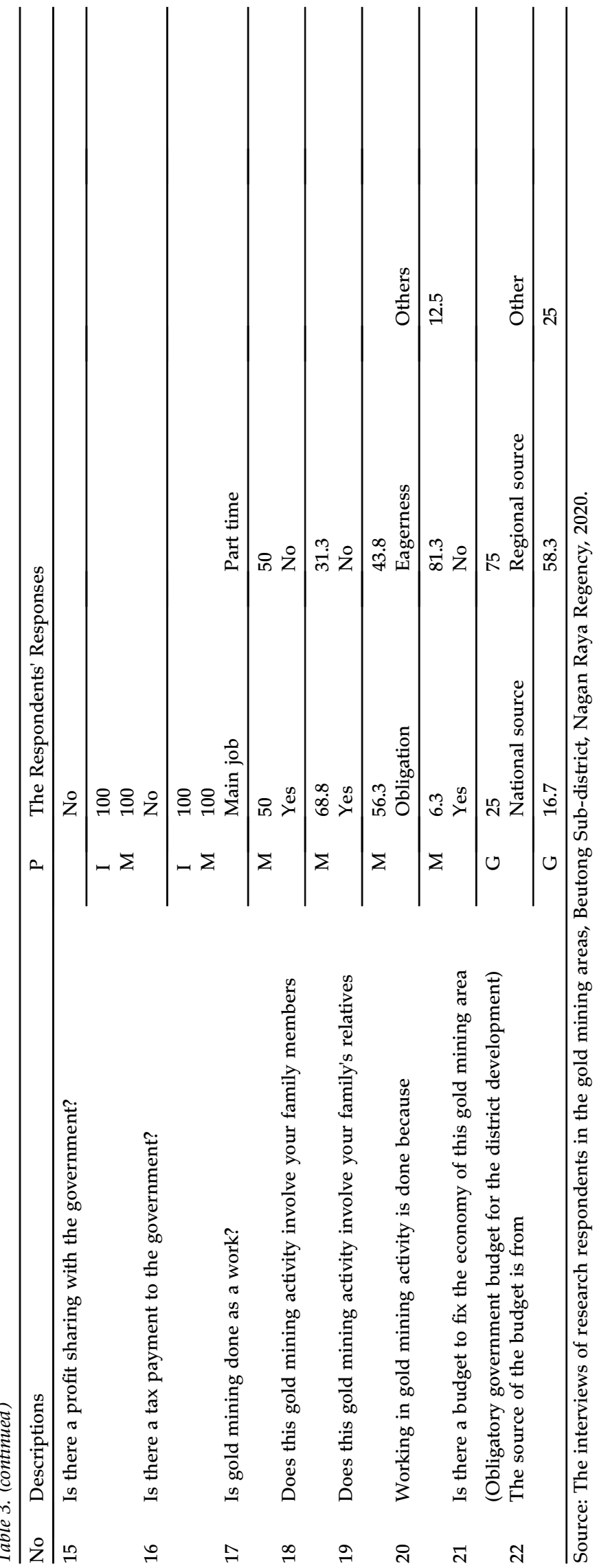

miners. Moreover, owners and investors in the company get a lot of benefits from them. This happens because the owners and investors are not bound by laws and regulations.

A lack of social benefits. Social benefits can be in the form of public facilities that can be enjoyed by the surrounding community, such as health and education facilities, security and hygiene facilities, and other facilities and infrastructure such as a playground for children, clean and comfortable public bathrooms and so on. As a company that manages resources and gets profits from these activities, owners and investors obtain big profits from the management of these natural resources, but the people who live around this area will bear the risks arising from excess environmental damage and forest destruction. Therefore, owners and investors should contribute to the development of this area, in terms of both physical development and the development of social relationships. All public facilities in the Beutong area have been built and provided by the local government. More than $90 \%$ of the community members said that owners and investors do not contribute to empowering the community in social terms.

Population increases. This IGM creates jobs $[9,28]$ for anyone who wants them because there are no rules that must be followed. This encourages immigrants to come to this area with the aim of mining gold $(56.3 \%)$ and other purposes $(43.7 \%)$. The positive impact of this population increase is to increase interaction and diversity of the population and increase competitiveness among miners so that the impact of the laziness of the indigenous population can be reduced. Negative impacts arise when competition among miners triggers conflict.

Table 3 represents some economic aspects arising from the existence of the IGM in Beutong Sub-district, namely higher revenue, no tax/profit sharing, and big opportunities for labor without skills good enough to get other jobs, as follows:

Higher revenue. IGM activity increases the income of local communities [3,9], miners, owners and investors. They earn a fantastic amount from the gold that is mined and this is supported by the attractive gold price level in the market [9]. However, Owusu et al. [3] have a different opinion from Boadi [9], which is that the most important factor affecting income growth is the production of gold, not its price. Therefore, increasing mining revenue, reducing unemployment, and increasing local trade can be accomplished by significantly increasing working hours. This research shows that both of these aspects are important as indicated by the range of the amount of IGM product between 10 and $100 \mathrm{~g}$ and even more than $100 \mathrm{~g}$ per day with 
gold prices ranging from IDR 700,000 to 800,000 per gram. This is highly dependent on backhoes as a tool in carrying out the mining activities as well as several mining locations that are active. This situation means the direct parties involved continue to carry out their operations, even though the obstacles in the mining field are very varied and quite substantial.

No tax/profit sharing. The income earned from IGM is not subject to tax or profit sharing with the government as is the case with legal mining [29]. Almost all parties involved pay no tax and do not engage in profit sharing with local government.

Big opportunities for labor without skills good enough to get other jobs. In addition, the absorption of labor needed to carry out IGM activities is quite high, especially for people who live in Beutong Sub-district. However, the absorption of these workers is not only the workers from Beutong Sub-district but also from the outside the area. This means that the workforce involved in gold mining activities are from Aceh and outside Aceh. The identified workforce classification is skilled labor (used to run backhoes and operational techniques for gold mining operations) and unskilled labor (Table 1).

\subsection{The IGM impact on environmental damage and vulnerability of local community to disaster}

IGM activities cause problems with environmental damage such as deforestation, water pollution, poor fertility of soil, and limited access to land for agricultural productivity [8]. Furthermore, Rice et al. [30] stress that the long-term use of mercury can also damage the environment. Mercury will enter the soil and then will make the groundwater toxic which will endanger human life [30]. Thus far, IGM activities in Beutong Sub-district avoid the use of mercury in the process of separating gold ore from other metals, soil, and rock. The gold mining community uses "asbhuk" as a means of separating gold ore from other metals, soil, and rock. The operation of $a s b h u k$ is very dependent on the availability of sufficient water because it will be sprayed on the dredged chunks of soil using a backhoe which is placed on top of the asbhuk. Using sufficient water power will enable the separation of the rock and soil and further separate the soil from the gold ore contained in the chunk of soil. Therefore, in general, IGM is carried out in plain locations that have sufficient water availability from rivers near the mining site. These are the negative impacts of IGM that are experienced by the local community consisting of the changes in the structure of mining lands, forest encroachment, and the expansion of the vast river surface. Furthermore, these conditions have triggered several natural disasters that have occurred in this area such as floods from overflowing rivers and landslides. This is due to the heavy rainfall that can no longer be stored in the soil structure and forest function that have been damaged by mining activities (Fig. 2 and Table 4).
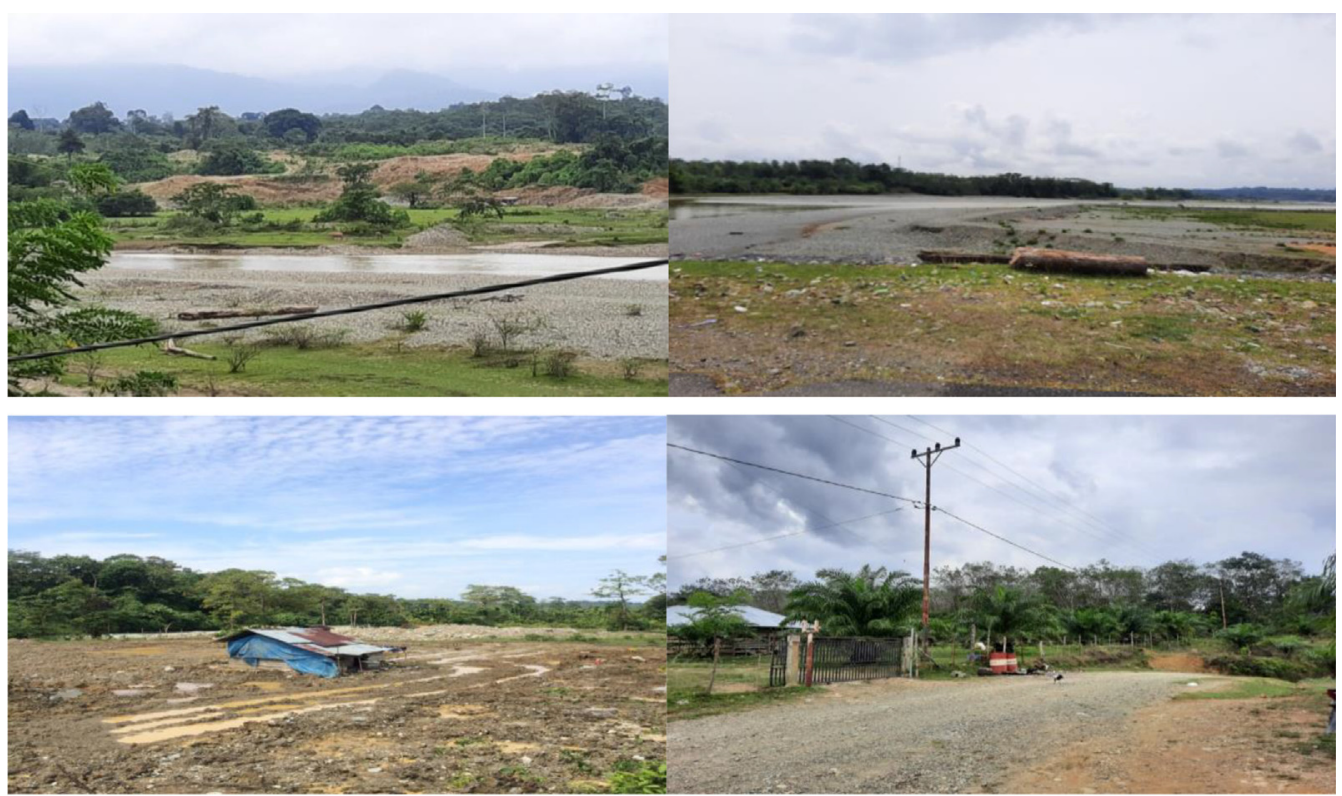

Source: Gold Mining Location, River Surface Expansion, Ex-Mining Land Rehabilitation, and Reforestation of Oil Palm and Rubber Trees, 2020

Fig. 2. IGM location and environment in plain and River areas (Riverbanks). 


\section{No Descriptions \\ 1 Fuel used for daily gold mining activity (daily needs)}

$$
\text { Fuel used for daily gold mining activity (daily needs) }
$$

2 Is there available electricity for lighting the gold mining activity

Is there any use of mercury for this gold mining activity?

4 Is there any use of heavy equipment for gold mining activity

$5 \quad$ Has it ever happened natural disaster?

6 Water sources used for daily needs

7 The state of the water used for daily purposes (hives)

8 The water used for daily purposes

9 Have the local people ever experienced water poisoning

10 Have the surrounding community experienced lung, kidney, heart, liver diseases (cancer)?
P The Respondents' Responses

\begin{tabular}{llllll} 
& Gas & Kerosene & Gas \& Kerosene & Diesel oil & Firewood/Others \\
\hline $\mathrm{O}$ & 27.8 & & & 55.6 & 16.7 \\
$\mathrm{M}$ & 6.3 & & 87.5 & 6.3 \\
$\mathrm{C}$ & 42.1 & 42.1 & 5.3 & & 10.5 \\
& Yes & No & & &
\end{tabular}

O 33.3

M 31.3

C 84.2

66.7

68.8

\begin{tabular}{llll} 
& Yes & Yes, a little & No \\
\hline O & 5.6 & 5.6 & 88.9 \\
M & 12.5 & 43.8 & 43.8 \\
G & 33.3 & & 66.7 \\
& Yes & No & \\
\hline
\end{tabular}

O 100

M 100

G $\quad 91.7$

\begin{tabular}{llll} 
& Flood/Overflow of river water & Other (Landslide) & Never \\
\hline O & 22.2 & 11.1 & 66.7 \\
M & 18.8 & 6.3 & 75.0 \\
G & 16.6 & 25 & 58.3 \\
C & 15.8 & 26.3 & 57.9 \\
& Well & River & Well and river \\
\hline O & 66.7 & 22.2 & 11.1 \\
M & 56.3 & 37.5 & 6.3 \\
& Never (Fresh) & Cloudy & \\
\hline
\end{tabular}

O 100

M 100

C 84.2

\begin{tabular}{llllll} 
& Pipeline water & Well & River & Well and river & Rain \\
\hline G & & 25 & 66.7 & & 8.3 \\
C & 5.3 & 68.4 & 10.5 & 15.8 & \\
& Seldom & Never & & & \\
\hline
\end{tabular}

O 5.6

94.4

G $\quad 16.7$

Seldom

83.3

Never Little

$\begin{array}{lll}\text { O } & 5.6 & 94.4\end{array}$

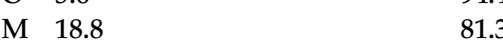

$\begin{array}{lll}\mathrm{G} & 16.6 & 75 \\ \mathrm{C} & 47.4 & 52.6\end{array}$ 


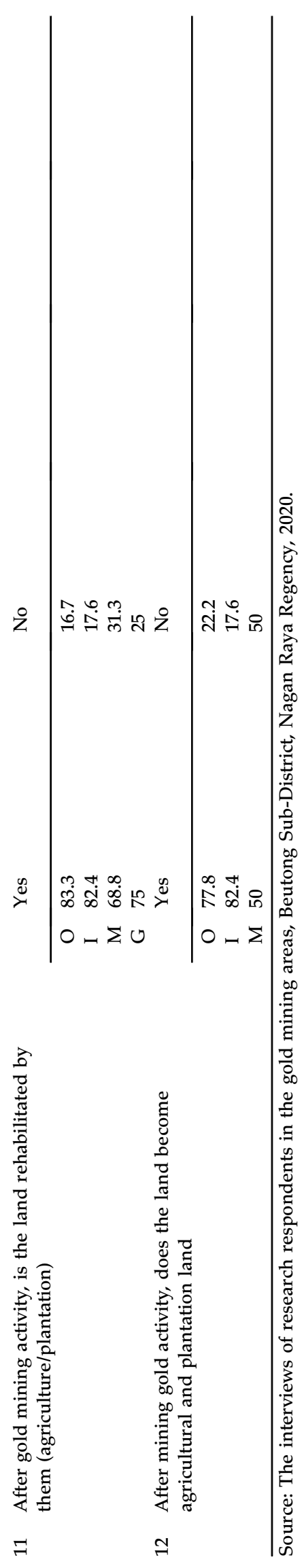

However, several parties in IGM have paid attention to the existence of changes in soil structure and forest function. This can be seen in the backfilling and leveling. Some have even replanted plantation trees on the former IGM land, such as palm trees and rubber trees. This is done to reduce the vulnerability of local communities to potential natural disasters such as floods and landslides. Apollo et al. [31] highly recommend involving the community, forming partnerships, and using modern technology and mine management strategies to influence the reduction of environmental degradation.

\subsection{The IGM impact on potential conflict}

IGM activities can lead to conflicts between interested parties because there are no regulations that can reduce the negative effects of their competing interests [32]. Potential conflicts arise over seizure of mining areas and disputed ownership [32], and differences in perceptions and attitudes towards the impact of IGM [8]. In contrast to the literature on this matter, in the Beutong case, the potential for conflict originates from differences in the wishes of the owners, investors and local government regarding the management of this mining area. A small proportion of the owners of IGM (38\%) want this mining to continue without local government interference. Meanwhile, most of the other IGM owners want a change the mining status so it becomes legal. However, the owners of the IGM want their management to be handled by individuals and small-scale groups (83.3\%). Also, owners of IGM want local government management of this IGM $(72.2 \%)$. In fact, the owners of these IGMs want an official permit from the local government for their IGM activity $(100 \%)$ and are open to other community members carrying out this gold mining legally.

There is optimistism on the part of the investors in IGM. However, the degree of optimism for investors is lower than the owners of the IGMs regarding the current gold mining conditions. Miners working in IGM also want the same thing, but it is just that the openness of mining land for other community members to carry out gold mining on is somewhat limited. Overall, so far, the IGM parties want greater involvement of local government management and want a greater local government involvement in granting mining licenses. Moreover, the direct IGM parties want the gold exploitation activities to be carried out by them with small group as legal artisanal and small-scale gold mining. The same pattern is also desired by the community around the 
Table 5. The expectations of respondents (in percentage).

\begin{tabular}{|c|c|c|c|c|c|}
\hline \multirow{2}{*}{$\frac{\text { No }}{1}$} & \multirow{2}{*}{$\begin{array}{l}\text { Descriptions } \\
\text { Gold mining activity runs like this forever }\end{array}$} & \multirow[t]{2}{*}{$\mathrm{P}$} & \multicolumn{3}{|c|}{ The Respondents' Responses } \\
\hline & & & Yes & No & Do not know \\
\hline & & $\mathrm{O}$ & 33.3 & 66.7 & \\
\hline & & I & 17.6 & 82.4 & \\
\hline & & M & 37.5 & 75 & \\
\hline & & G & 16.7 & 83.3 & \\
\hline & & $\mathrm{C}$ & 26.3 & 52.6 & 21.1 \\
\hline \multirow[t]{6}{*}{2} & Gold mining activity isn't done like this forever & & Yes & No & Do not know \\
\hline & & $\mathrm{O}$ & 61.1 & 38.9 & \\
\hline & & I & 47.1 & 52.9 & \\
\hline & & M & 31.3 & 68.8 & \\
\hline & & G & 83.3 & 16.7 & \\
\hline & & C & 26.3 & 57.9 & 15.8 \\
\hline \multirow[t]{6}{*}{3} & Gold mining activity should be carried out & & Yes & No & Do not know \\
\hline & & $\mathrm{O}$ & 72.2 & 27.8 & \\
\hline & & I & 70.6 & 29.4 & \\
\hline & & $\mathrm{M}$ & 68.8 & 31.3 & \\
\hline & & G & 91.7 & 8.3 & \\
\hline & & $\mathrm{C}$ & 52.6 & 31.6 & 15.8 \\
\hline \multirow[t]{6}{*}{4} & Gold mining activity should be done with & & Yes & No & \\
\hline & & $\mathrm{O}$ & 83.3 & 16.7 & \\
\hline & & I & 64.7 & 35.3 & \\
\hline & & M & 93.8 & 6.3 & \\
\hline & & G & & 100 & \\
\hline & & C & 36.8 & 63.2 & \\
\hline \multirow[t]{6}{*}{5} & Gold mining activity should be carried out & & Yes & No & \\
\hline & & $\mathrm{O}$ & 27.8 & 72.2 & \\
\hline & & I & 52.9 & 47.1 & \\
\hline & & M & 31.3 & 68.8 & \\
\hline & & G & 100 & & \\
\hline & & $\mathrm{C}$ & 57.9 & 42.1 & \\
\hline \multirow[t]{6}{*}{6} & The local government hopes for this & & Open to other residents & Closed to other residents & Closed to all \\
\hline & & $\mathrm{O}$ & 88.9 & 11.1 & \\
\hline & & I & 100 & & \\
\hline & & M & 68.8 & 31.3 & \\
\hline & & G & 100 & & \\
\hline & & $\mathrm{C}$ & 26.3 & 36.8 & 36.8 \\
\hline \multirow[t]{6}{*}{7} & Gold mining activity is supposed to be done with & & Local gov.t permits & Without local gov. permits & \\
\hline & & $\mathrm{O}$ & 100 & & \\
\hline & & I & 94.1 & 5.9 & \\
\hline & & M & 81.3 & 18.8 & \\
\hline & & G & 100 & & \\
\hline & & $\mathrm{C}$ & 84.2 & 15.8 & \\
\hline
\end{tabular}

Source: The interviews of research respondents in the gold mining areas, Beutong Sub-District, Nagan Raya Regency, 2020.

mining area. Nevertheless, they want this gold mining activity to be less open to other residents.

As for the indirect parties' side of this, the government desires all forms of gold mining activities to be subject to local government permits $(100 \%)$ and be managed closely by the local government. However, the implementation of this gold mining activity must be carried out in large groups and not small groups; furthermore, it must also be open to other residents to be able to carry out gold exploitation activities at the mining location. Table 5 depicts the expectations of direct and indirect IGM respondents in Beutong Sub-district, Nagan Raya Regency with regards to potential conflict.

Overall, thus far, there has been no significant conflict resulting from IGM activities. It is just the wish of the direct parties in IGM activities, with regard to the implementation of this gold mining activity, for it to be carried out by artisanal and small-scale and not by large-scale. This condition 


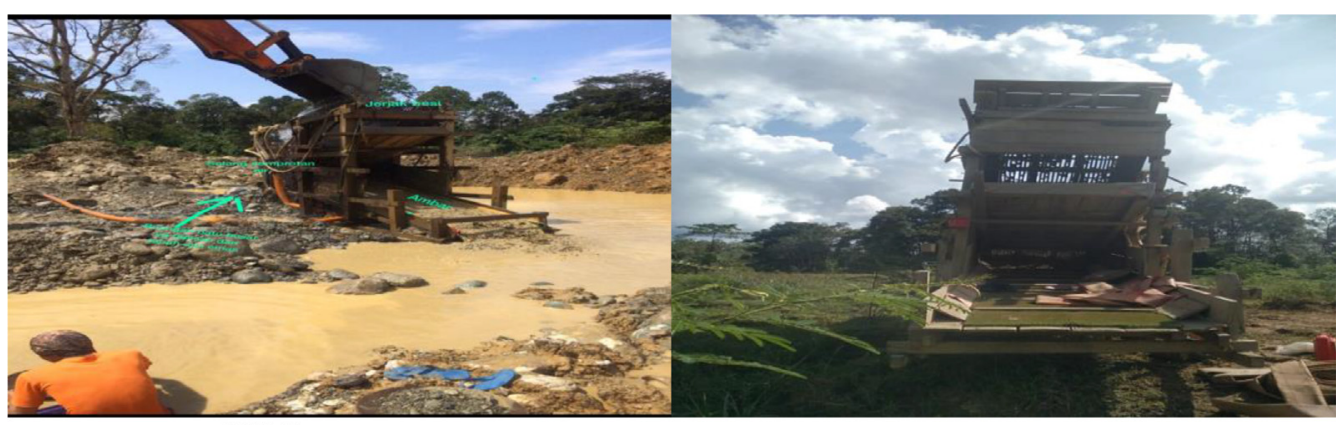

Source: Asbhuk, IGM Location, and Backhoe, 2020

Fig. 3. IGM process using Asbhuk and Backhoe in plain and River areas (Riverbanks).

provides a very positive signal for the implementation of mining activities legally. This is indicated by the positive desire of IGM parties in Beutong Subdistrict, both those who are directly or indirectly involved with this gold mining activity. This common desire can soon be formulated in the form of comprehensive regulations related to making this gold mining exploitation activity legal. Not only related to the legality of gold mining in the form of mining exploitation management, but also related to the management of mining land rehabilitation, reforestation of mining land with productive trees, the technology used to be friendly to the surrounding natural environment, as well as management of mining products with added value in terms of the welfare of society as a whole. This makes it possible for local governments to establish local companies on a national and even international scale that can be used as a driver to accelerate sustainable economic growth in Aceh as a whole. Owusu et al. [3] argue that this is important because sustainable reform can ensure socio-environmental sustainability through increasing local participation in decision making, education and training, adoption of better technology, strengthening regulatory institutions, enacting legislation and law enforcement, and providing technical and logistical support. This is also reinforced by Apollo et al. [31], who say that the community participation, partnerships,

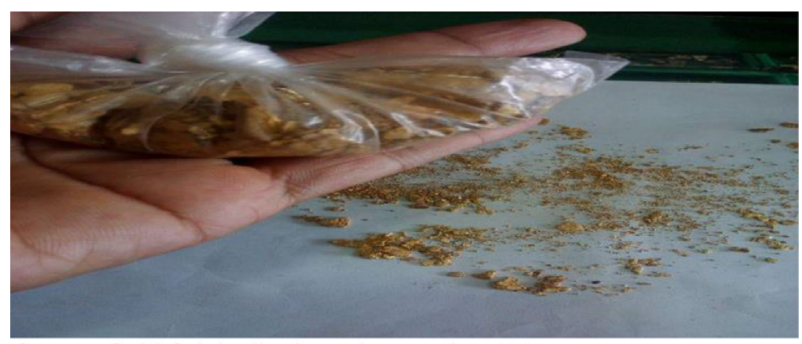

Source: Gold Originality is ready to trade, 2020

Fig. 4. Gold Originally from IGM Which is Ready to Trade. modern technology, and mine management strategies all have a big role in reducing the environmental degradation and strengthening sustainability.

\subsection{The IGM and alternative technology solution}

In fact, the IGM in Beutong Sub-district, Nagan Raya Regency, is carried out by paying attention to environmental friendliness with regard to community life around the mine, in particular, and the natural surroundings. This is shown by the use of gold mining exploitation tools with traditional characteristics. The name of the traditional tool used in screening for gold mining ore is known as asbhuk. An asbhuk is used to replace the use of mercury in the gold refining process in the mining area. An asbhuk is made of wood and is very strong because it will accommodate the load of chunks of soil dredged using a backhoe. The specifics of an asbhuk can be seen in Fig. 3 .

Fig. 3 shows that an asbhuk is made of wood with a "sloping V" shape. The first part is the top layer which is given an iron truss with several transverse pieces of wood which are useful for separating stone, soil, and gold. Stones will be thrown out, while soil and gold will enter between the iron bars with the help of continuously spraying water. After that, land and gold enter the second part of then asbhuk together with the fall of the water. In this second layer, an asbhuk is equipped with a layer of carpet that is used to accommodate the gold ore which enters between the small holes in the carpet. Meanwhile, the soil, along with the bursting water in the upper layer will flow back into the river. The gold exploitation process was assisted by a backhoe which accelerates it and makes it easier for this gold mining method, to obtain optimal results. The average gold miner can obtain between 20 and $100 \mathrm{~g}$ of gold per day, and even more than $100 \mathrm{~g}$ per day sometimes. 


\subsection{Regulations establishing legality of gold mining activity and adding value}

In the regulatory context, gold mining in the Beutong Sub-district of Nagan Raya Regency is still illegal. This is indicated by the complete halt of gold exploitation at these IGM locations in 2018. Even in that year, the ESDM office (Department of Energy and Mineral Resources) of Nagan Raya Regency was no longer domiciled in Nagan Raya Regency but had moved to the capital of Aceh Province. This situation made it even more difficult for the traditional gold mining community to manage and obtain legal mining status. This is caused by the cost of processing legal gold mining being increasingly expensive and the long wait for the community before getting legal gold mining status. Previously, the IGM community had tried to obtain legalization of the gold mining from the ESDM Office of Nagan Raya Regency. However, the attempt failed. This was due to the strict requirements and procedures for mining business legalization that had to be met, such as very high environmental costs in the form of reforestation funds, Corporate Social Responsibility (CSR), and the other legal requirements. In view of the strictness of these terms and procedures, it is necessary to have intensive and structured intervention from the local government of Aceh Province to address the gold mining legality issue. As an alternative to local government policy, it is hoped that the local government will create a regional company that collaborates with the local IGM community to meet the legal standards for gold mining. If not, these circumstances can have an impact on the pattern of IGM activities meaning they will be carried out individually and small-scale group, not massively (moving around), and secretly.

In addition, the product of IGM is sold directly to local, national, and even international collectors. This means that mine owners, investors, and the gold mining community, as direct parties, carry out the process of selling their produce without a process for increasing added-value. Even if there is, it is still on a small scale and is traditionally processed. This situation is very detrimental to the regional and even national economy because the added value for the economy from the gold mining products is not enjoyed by the regions nor even by the state. For this reason, it is necessary to have management of gold mining products managed professionally by the local government, so that the added value for the economy can be observed as a whole by the local community and even nationally. Therefore, the existence of regional companies needs to be actualized in real terms as one of the mining economic sub- sectors that are capable of driving the regional economy as a whole and in a modern way. Fig. 4 shows the original form of gold that is ready to be sold to collectors.

\section{Conclusion}

This study aims to analyze, from social-economics and environmental perspectives, how IGM in Aceh survives and grows with its illegal status. Specifically, this study investigates the impact of the existence of IGM on socio-economic life, environmental damage, potential conflicts between parties who are directly involved (miners, mine owners, and investors) and parties who are not directly involved, such as local governments and communities around the mining area, to analyze why IGM is able to survive and expand. Besides, this study analyzes the impact of the existence of IGM on the level of vulnerability of local communities to disasters.

In general, exploitation activities of IGM have a positive impact on the socio-economy of the parties who are involved especially the owners and investors. Some socio-economic aspects of their lives improve. As is customary with IGM, there are no binding regulations that guarantee the welfare of society from a social aspect, so some social impacts that should not have happened actually do so because of the absence of the regulations. Higher revenue, no tax, and no profit sharing are the benefits for owners and investors, the miners, and the community as a result of the existence of IGM in Beuthong. The increase in income is not only felt by the owners and investors, but also by miners and the community who increase their income by carrying out this illegal IGM. The income earned from IGM is not subject to tax or profit sharing with the government in the way it is with legal mining. Almost all parties involved in IGM pay no tax and do not engtage in profit sharing with the state and local government. This is detrimental to the state and regions because environmental and forest damage arising from this mining will be borne by the state and local governments.

The other benefit for the community on the economic side is a lot of opportunities for workers without good skills to get jobs. People who do not have certain skills find it difficult to find jobs that require expertise. Traditional mining activities using sieves do not require certain expertise. Activities like this are the main focus of unskilled workers. The absorption of labor needed to carry out gold mining activities is also quite large. Local people, especially for people who live in Beutong Sub- 
district and around the mining area, do not have good skills to get other jobs outside the area. They make use of these natural resources to support themselves. However, the absorption of these workers is not only the workers from Beutong Subdistrict in Aceh, but also from outside Aceh.

The added value for IGM products is still very low because these IGM products are sold directly to local, national, and even international collectors. This means that mine owners, investors, and the gold mining community, as the direct parties of gold mining, do not carry out the process of increasing added value related to the yield of gold they have mined. Even if there is, it is still on a small scale and is processed traditionally. This situation is very detrimental to the regional economy and even the national economy.

Young laborers work at risk without guarantees, lacking social benefits. Also, population increase is a negative impact of IGM from the social point of view. The bad consequences of IGM in terms of the social aspects of community life around the mining area occur because there are no regulations that control the rights and obligations of the parties involved in this activity, namely environmental, forest and water rights, and other rules that bind social life of community. As long as the mining status is illegal, there can be no regulation. The other social aspect, access between regions, is easier due to the use of rivers as a means of transportation between IGM areas. The inter-village transportation route in Beutong Sub-district is a land route with an asphalt or concrete road surface and still only six villages have good land road surface conditions. This facilitates land access to nearby districts, regencies, and even interagencies. Particularly in gold mining areas, apart from the roads used, river routes greatly affect the gold mining activities. Indeed, the flow of river water also really helps miners in the IGM process because asbhuks is very close to a source of water as a liquefier for the initial separation of soil and stone, as well as soil and gold.

IGM activities cause deforestation of protected forests which need serious restoration efforts. Large trees that are tens or even hundreds of years old that function as a buffer for groundwater have been felled when miners open new mining areas in protected forest areas. Some miners try to replant trees in areas they have logged, but not all of them do this. However, the trees' function as a binding agent for groundwater has diminished. If the felling of these trees continues, it is feared that the Beutong area will become an area prone to floods. On the environmental side, so far, the IGM activities in Beutong Sub-district have not caused serious environmental damage. The gold mining community in the area does not use mercury to separate gold dust from metal ore. They use asbhuks or sluice boxes which are very large and made of wood, so they can accommodate large amounts of soil and sand. Using this very simple-but very environmentally friendly-tool, means that it does not harm the sustainability of the natural environment of the people around Beutong Sub-district, especially the use of wells and mountain springs. However, natural disasters often occur in this area, such as overflowing rivers and landslides caused by heavy rainfall. This is a negative impact from changes in the structure of mining land, forest encroachment, and the expansion of the river surface which is very wide as a negative consequence of the IGM activities.

There is no significant conflict between direct and indirect parties engaged in IGM activities. It is just that the direct parties involved in gold mining activities desire this gold mining activity to be artisanal and small-scale not large-scale. This common desire can immediately be formulated in terms of regulations that will legally protect all interests involved in this gold mining exploitation. In general, an increased role on the part of local governments is very much needed in managing these gold mines in the form of structuring gold mines with legal status in order to be exploited in an environmentally friendly way. The status of a legal gold mine can be in the form of a gold mining cooperative or a regional company. It is hoped that this gold mining business, whether in the form of a cooperative or a regional company, the government can (a) protect the gold price that is profitable for the gold miners which rely on it for their livelihoods; (b) maintain price stability by optimizing the government's function as a collector for the gold mining produce; (c) increase the added value of gold which has a better level of competitiveness; (c) open up a more competitive market for gold mining products, so that the monopoly and monopsony of the gold mine do not occur. If this form of business is formulated, the government can conduct environmentally friendly mining management, which can be realized by local regulations that are binding on the gold mining parties.

\section{Policy implications}

Based on the positive and negative impact of illegal mining on the environment, livelihood, and social life of all stakeholders, there are several recommendations that the authors can convey, especially to the local government of Nagan Raya, Aceh Province, and the central government of Indonesia. 
There are contradictory interests among owners, investors, miners, communities, and the government that must be considered in managing this mine. Owners, investors, and miners want this mine to continue to be managed by artisanal and smallscale gold mining and given legal status because they claim that the mining land belongs to them. The community around the mining area also agrees that they will continue to manage this gold mining and they will be given legal status. Meanwhile, the local government wants the mine to be managed and controlled by the state. The regulation requires the management of class a mine to be controlled by the state. The government and society must comply with the regulations. This situation is a dilemma. Therefore, this study provides recommendations to accommodate all interests to avoid prolonged conflicts that can exacerbate the damage to the environment and forest by not ignoring regulatory provisions. We recommend the establishment of artisanal and small-scale gold mining to exploit this mine in the legal framework. Owners, investors, and miners would continue to carry out their work as usual. However, there would be a contribution as profit-sharing or tax-payment by the owners and investors for the government. Owners, investors, and miners would be obliged to pay taxes. Some regulations which would have to be obeyed would contain applicable terms and conditions and govern the rights and obligations of all parties involved. Artisanal and small-scale gold mining also contribute to empowering communities around the mine and the quality of the community's overall socio-economic development.

\section{Conflicts of interest}

None declared.

\section{Ethical statement}

The authors state that the research was conducted according to ethical standards.

\section{Funding body}

We gratefully acknowledge the financial support of Universitas Syiah Kuala (USK) who provided funding for this research under research contract number 266/UN11/SPK/PNBP/2020, March 17th, 2020.

\section{Acknowledgements}

The author would like to thank the team of local enumerators who have gone to great lengths to help the research team to obtain information by distributing questionnaires and indepth-interviews to owners, investors, miners, local governments, and communities around illegal gold mines which are very closed and secret. In addition, the team of local enumerators faced very tough natural challenges in the field. Walking in mountainous areas, through several rivers by means of a raft crossing, and being far from the village to get this research information can be completed well. Hopefully, this research will be more valuable and useful for the sustainability of gold mining in Indonesia and in the world.

\section{References}

[1] Haundi T, Tsokonombwe G, Ghambi S, Mkandawire T, Kasambara A. An investigation of the socio-economic benefits of small-scale gold mining in Malawi. Mining 2021;1: 19-34. https://doi.org/10.3390/mining101003.

[2] Mkodzongi Grasian, Spiegel Samuel. Artisanal gold mining and farming: livelihood linkages and labour dynamics after land reforms in Zimbabwe. J Dev Stud 2019;55(No. 10): 2145-61. https://doi.org/10.1080/00220388.2018.1516867.

[3] Owusu O, Bansah KJ, Mensah AK. "Small in size, but big in impact": socio-environmental reforms for sustainable artisanal and small-scale mining. J Sustain Min 2019;18(1): 38-44. https://doi.org/10.1016/j.jsm.2019.02.001.

[4] Adonteng-Kissi O, Adonteng-Kissi B, Asamoah E. Mining versus farming: an analysis of the farmers' livelihood system. Int J Sustain Econ Soc Cult Context 2016;12(2). https://www. researchgate.net/publication/301302918.

[5] Adonteng-Kissi O. Poverty and mine's compensation package: experiences of local farmers in Prestea mining community. Resour Pol 2017;52:226-34. https://doi.org/10.1016/j. resourpol.2017.03.007.

[6] Adonteng-Kissi O, Adonteng-Kissi B. Living with conflicts in Ghana's Prestea mining area: is community engagement the answer? J Sustain Min 2017;16(4):196-206. https://doi.org/10. 1016/j.jsm.2017.12.005.

[7] Bansah JK, Dumakor-Dupey KN, Kansake AB, Assan E, Bekui P. Socioeconomic and environmental assessment of informal artisanal and small-scale mining in Ghana. J Clean Prod 2018;202:465-75. https://doi.org/10.1016/j.jclepro.2018. 08.150.

[8] Obeng EA, Oduro KA, Obiri BD, Abukari H, Guuroh RT, Djagbletey GD, et al. Impact of illegal mining activities on forest ecosystem services: local communities' attitudes and willingness to participate in restoration activities in Ghana. Heliyon 2019;5(10):e02617. https://doi.org/10.1016/j.heliyon. 2019.e02617.

[9] Boadi S, Nsor CA, Antobre OO, Acquah E. An analysis of illegal mining on the Offin shelterbelt forest reserve, Ghana: implications on community livelihood. J Sustain Min 2016; 15(3):115-9. https://doi.org/10.1016/j.jsm.2016.12.001.

[10] The 1945 Constitution of the Republic of Indonesia. The 1945 Constitution of the Republic of Indonesia (Undang-Undang Dasar Republik Indonesia 1945). 1945.

[11] Duff PM, Downs TJ. Frontline narratives on sustainable development challenges/opportunities in the "illegal" gold mining region of Madre de Dios, Peru: informing an integrative collaborative response. Extract Indust Soc 2019;6(2): 552-61. https://doi.org/10.1016/j.exis.2019.01.005.

[12] Development Database of Nagan Raya Regency. Development Database of Nagan Raya regency 2017. Aceh Province: Development Planning Agency of Nagan Raya Regency; 2017.

[13] Development Database of Beutong Sub-District of Nagan Raya Regency. Development Database of Beutong sub- 
District of Nagan Raya Regency 2017. Aceh Province: Development Planning Agency of Nagan Raya Regency; 2017.

[14] Dery Tuokuu FX, Kpinpuo SD, Hinson RE. Sustainable development in Ghana's gold mines: clarifying the stakeholder's perspective. J Sustain Min 2019;18(2):77-84. https:// doi.org/10.1016/j.jsm.2019.02.007.

[15] Monteiro RBN, da Silva AE, Neto MMJ. Sustainable development goals in mining. J Clean Prod 2019;228:509-20. https://doi.org/10.1016/j.jclepro.2019.04.332.

[16] Omotehinse AO, Ako BD. The environmental implications of the exploration and exploitation of solid minerals in Nigeria with a special focus on Tin in Jos and Coal in Enugu. J Sustain Min 2019;18(1):18-24. https://doi.org/10.1016/j.jsm. 2018.12.001.

[17] Amoah N, Stemn E. Siting a centralised processing centre for artisanal and small-scale mining - a spatial multi-criteria approach. J Sustain Min 2018;17(4):215-25. https://doi.org/ 10.1016/j.jsm.2018.10.001.

[18] Sánchez-Vázquez L, Espinosa-Quezada MG, EguigurenRiofrío MB. "Golden reality" or the "reality of gold": artisanal mining and socio-environmental conflict in Chinapintza, Ecuador. Extract Indust Soc 2016;3(1):124-8. https://doi.org/ 10.1016/j.exis.2015.11.004.

[19] Al Rawashdeh R, Campbell G, Titi A. The socio-economic impacts of mining on local communities: the case of Jordan. Extract Indust Soc 2016;3(2):494-507. https://doi.org/10.1016/ j.exis.2016.02.001.

[20] Horsley J, Prout S, Tonts M, Ali SH. Sustainable livelihoods and indicators for regional development in mining economies. Extract Indust Soc 2015;2(2):368-80. https://doi.org/10. 1016/j.exis.2014.12.001.

[21] Kitula AGN. The environmental and socio-economic impacts of mining on local livelihoods in Tanzania: a case study of Geita District. J Clean Prod 2006;14(3-4):405-14. https://doi. org/10.1016/j.jclepro.2004.01.012.

[22] García O, Veiga MM, Cordy P, Suescún OE, Molina JM, Roeser M. Artisanal gold mining in Antioquia, Colombia: a successful case of mercury reduction. J Clean Prod 2015;90: 244-52. https://doi.org/10.1016/j.jclepro.2014.11.032.
[23] Vieira R. Mercury-free gold mining technologies: possibilities for adoption in the Guianas. J Clean Prod 2006;14(3-4): 448-54. https://doi.org/10.1016/j.jclepro.2004.09.007.

[24] Law of the Republic of Indonesia. Law of the Republic of Indonesia No. 32/2009 regarding Protection and Management of the Environment (Undang-Undang Republik Indonesia No.32/2009 Tentang Perlindungan dan Pengelolaan Lingkungan Hidup). 2009.

[25] Aceh Government Regulation. Aceh Government Regulation No. 23/2016 regarding Criteria and Procedures in Providing Incentives for Environmental Management in Aceh (Peraturan Gubernur Aceh No. 23/2016 Tentang Kriteria dan Tata Cara Pemberian Insentif Pengelolaan Lingkungan Hidup di Aceh). 2006.

[26] Law of the Republic of Indonesia. Law of the Republic of Indonesia No. 4/2009 concerning Mineral and Coal Mining (Undang-Undang Republik Indonesia No.4/2009 Tentang Pertambangan Mineral dan Batubara). 2009.

[27] Nachinaab J, Azumah F. The effects of illegal gold mining on the education of children: a case study of Aniamoah community in the Atwima Mponua district, Ashanti regionGhana. Int J Innovat Res Adv Stud 2018;5(2):66-72.

[28] Chesney T, Evans K, Gold S, Trautrims A. Understanding labour exploitation in the Spanish agricultural sector using an agent based approach. J Clean Prod 2019;214:696-704. https://doi.org/10.1016/j.jclepro.2018.12.282.

[29] Romero M, Saavedra S. Local incentives and national tax evasion: Unintended effects of a mining reform in Colombia. Universidad Del Rosario Working Paper; 2019. p. 17529.

[30] Rice KM, Walker EM, Wu M, Gillette C, Blough ER. Environmental mercury and its toxic effects. J Prevent Med Publ Health 2014;47(2):74-83. https://doi.org/10.3961/jpmph.2014. 47.2.74.

[31] Apollo F, Ndinya A, Ogada M, Rop B. Feasibility and acceptability of environmental management strategies among artisan miners in Taita Taveta County, Kenya. J Sustain Min 2017;16(4):189-95. https://doi.org/10.1016/j. jsm.2017.12.003.

[32] Lakhani S, Corboz J. US Institute of Peace, US Institute of Peace 1-5 (2017). 2017. Retrieved from, https://www.jstor. org/stable/resrep20203. 